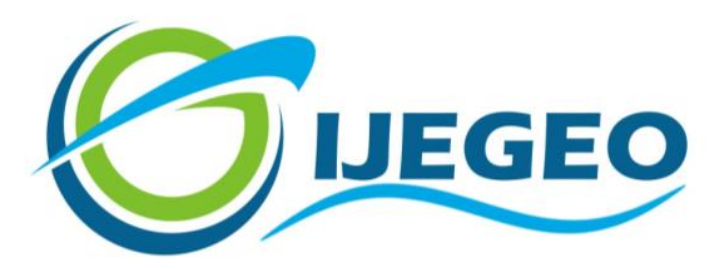

International Journal of Environment and Geoinformatics (IJEGEO) is an international, multidisciplinary, peer reviewed, open access journal.

\title{
New alien foraminifer guests in the Eastern Aegean Sea (Turkey)
}

\author{
Engin Meriç, M. Baki Yokeş, Niyazi Avşar, Zeki Ü. Yümün and Feyza Dinçer
}

\section{Editors}

Prof. Dr. Cem Gazioğlu, Prof. Dr. Dursun Zafer Şeker, Prof. Dr. Ayşegül Tanık, Assoc. Prof. Dr. Şinasi Kaya

\section{Scientific Committee}

Assoc. Prof. Dr. Hasan Abdullah (BL), Assist. Prof. Dr. Alias Abdulrahman (MAL), Assist. Prof. Dr. Abdullah Aksu, (TR); Prof. Dr. Hasan Atar (TR), Prof. Dr. Lale Balas (TR), Prof. Dr. Levent Bat (TR), Assoc. Prof. Dr. Füsun Balık Şanlı (TR), Prof. Dr. Nuray Balkıs Çağlar (TR), Prof. Dr. Bülent Bayram (TR), Prof. Dr. Şükrü T. Beşiktepe (TR), Dr. Luminita BUGA (RO); Prof. Dr. Z. Selmin Burak (TR), Assoc. Prof. Dr. Gürcan Büyüksalih (TR), Dr. Jadunandan Dash (UK), Assist. Prof. Dr. Volkan Demir (TR), Assoc. Prof. Dr. Hande Demirel (TR), Assoc. Prof. Dr. Nazlı Demirel (TR), Dr. Arta Dilo (NL), Prof. Dr. A. Evren Erginal (TR), Dr. Alessandra Giorgetti (IT); Assoc. Prof. Dr. Murat Gündüz (TR), Prof. Dr. Abdulaziz Güneroğlu (TR); Assoc. Prof. Dr. Kensuke Kawamura (JAPAN), Dr. Manik H. Kalubarme (INDIA); Prof. Dr. Fatmagül Kılıç (TR), Prof. Dr. Ufuk Kocabaş (TR), Prof. Dr. Hakan Kutoğlu (TR), Prof. Dr. Nebiye Musaoğlu (TR), Prof. Dr. Erhan Mutlu (TR), Assist. Prof. Dr. Hakan Öniz (TR), Assoc. Prof. Dr. Hasan Özdemir (TR), Prof. Dr. Haluk Özener (TR); Assoc. Prof. Dr. Barış Salihoğlu (TR), Prof. Dr. Elif Sertel (TR), Prof. Dr. Murat Sezgin (TR), Prof. Dr. Nüket Sivri (TR), Assoc. Prof. Dr. Uğur Şanlı (TR), Assoc. Prof. Dr. Seyfettin Taş (TR), Assoc. Prof. Dr. İ. Noyan Yılmaz (TR), Assist. Prof. Dr. Baki Yokeş (TR), Assist. Prof. Dr. Sibel Zeki (TR), Dr. Hakan Kaya (TR).

Abstracting and Indexing: Index Copernicus, Open Academic Journals Index, Scientific Indexing Services 


\title{
New alien foraminifer guests in the Eastern Aegean Sea (Turkey)
}

\author{
Engin Meriç ${ }^{1}$, M. Baki Yokeş ${ }^{2}$ Niyazi Avşarar ${ }^{3}$ Zeki Ü. Yümün ${ }^{4}$, Feyza Dinçer ${ }^{5}$ \\ ${ }^{1}$ Moda Hüseyin Bey Str. No: 15/4, 34710 Kadıköy İstanbul TR \\ ${ }^{2}$ AMBRD Laboratories Hanimefendi Str. No: 160/9 34384 Şişli İstanbul TR \\ ${ }^{3}$ Çukurova University, Department of Geological Engineering, 01330 Balcalı Adana TR \\ ${ }^{4}$ Namık Kemal University, Faculty of Engineering, Department of Environmental Engineering, 59860 Çorlu Tekirdağ- TR \\ ${ }^{5}$ Nevşehir Hacı Bektaş University, Faculty of Engineering and Architecture, Department of Geological Engineering, \\ 50300 Nevşehir TR
}

\begin{abstract}
Four alien foraminifer species are found in the recent sediment samples collected from the Aegean coast of Turkey. Nodobaculariella cristobalensis McCulloch and $N$. galapagosensis McCulloch are observed in Güllük Bay (Muğla), Karşıyaka (İzmir) and Babakale (Balıkesir). These two species have not yet been recorded in the Mediterranean. Their absence in the Indian Ocean fauna suggests an introduction via ballast waters. Two individuals of Indo-Pacific originated foraminifer species, Pseudonodosaria brevis (d'Orbigny, 1846) are found in the recent sediment samples from Ildır Bay (İzmir) and Akköy (Aydın). This constitutes the first records of these species in the Mediterranean Sea. Cornuspiroides striolata (Brady) specimens are observed in grab samples collected from seven different stations in Ildır Bay. This is the second record of this species from the Turkish coastline and extends its range of distribution.
\end{abstract}

Keywords: Cornuspiroides striolata, Nodobaculariella cristobalensis, Nodobaculariella galapagosensis, Pseudonodosaria brevis, foraminifera, alien species, Aegean Sea, Turkey

\section{Introduction}

Eastern Mediterranean is invaded by many marine alien species, majority of which are IndoPacific originated (Zenetos et al. 2012). With more than 70 alien species, the Foraminifera constitute the 6th largest alien group in the Mediterranean (Zenetos et al. 2008; Zenetos et al. 2012; Meriç et al. 2012a, b). Since most of these alien foraminifers are Indo-Pacific species and are found in the Red Sea fauna, Suez Canal is considered the main vector for their introduction. However, some of the alien benthic foraminifers recorded in the Aegean Sea, such as, Iridia diaphana Heron-Allen and Earland (Meriç et al. 2008b; Okuş et al., 2004, 2006), Euthymonacha polita (Chapman) (Meriç et al. 2010), Polymorphina fistulosa (Cushman) (Meriç et al. 2012a),

Dentalina albatrossi (Cushman) (Meriç et al. 2004) were not yet recorded elsewhere in the Mediterranean, indicating that these species might have been introduced not via Suez Canal, but by shipping.

During benthic surveys conducted in Ildır Bay (İzmir), Karşıyaka (İzmir), Akköy (Aydın), Güllük Bay (Muğla) and Babakale (Balıkesir) (eastern coast of Aegean Sea, Turkey), four alien foraminifer species were found in recent sediment samples. The findings of Nodobaculariella cristobalensis McCulloch, $N$. galapagosensis McCulloch and Pseudonodosaria brevis (d'Orbigny, 1846) have not yet been recorded elsewhere in the Mediterranean. The recent observation of Cornuspiroides striolata (Brady) constitutes the second record of this species in the Mediterranean and extends its range of distribution along the Turkish coastline. 


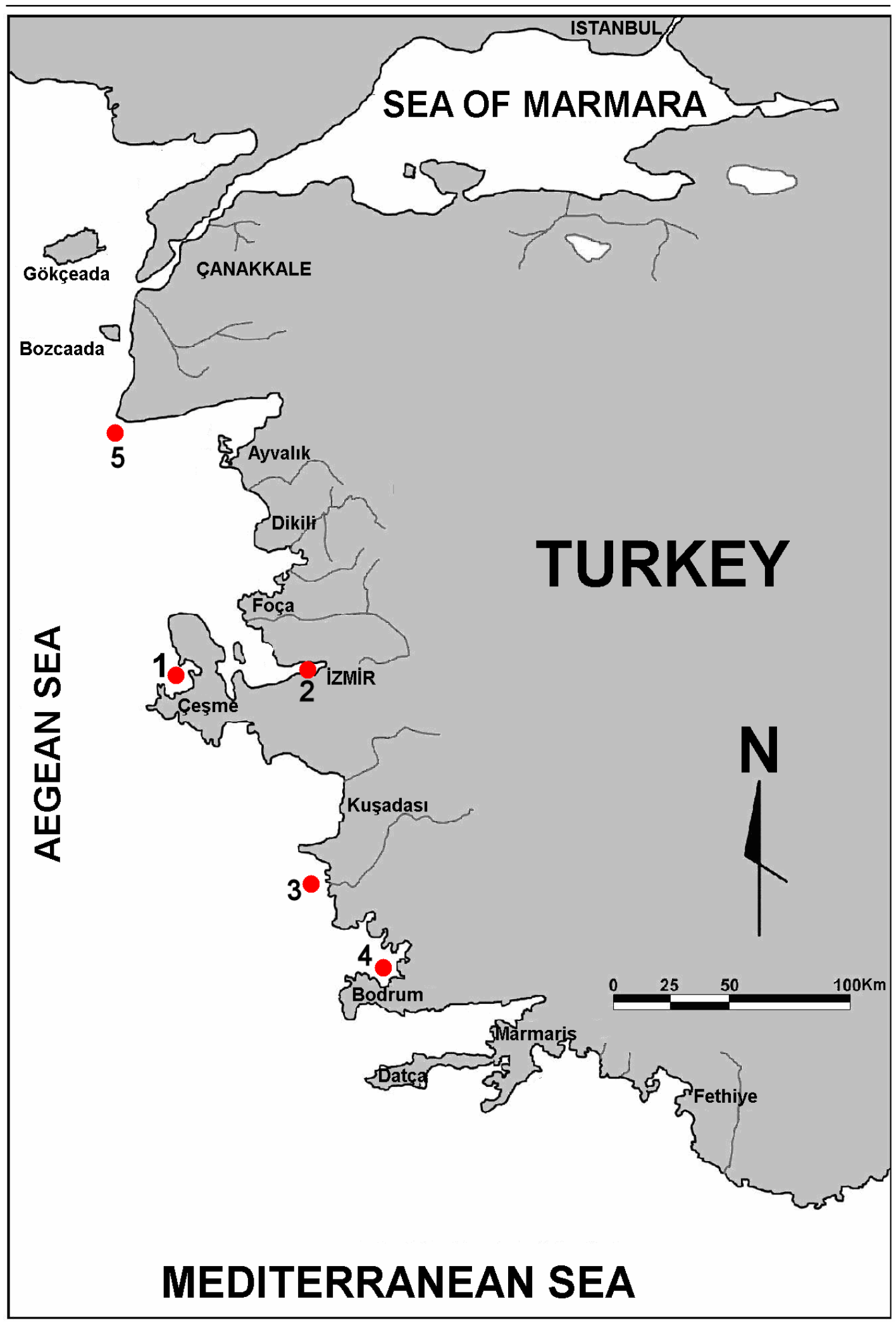

Fig. 1. Sampling locations: 1) Ildır, 2) Karşıyaka, 3) Akköy, 4) Güllük, 5) Babakale 


\section{Materials and Methods}

In April 2014 a benthic survey was conducted by R/V Koca Piri Reis and recent sediment samples were collected via Van Veen and box core samplers in Ildır Bay (10 stations), Güllük (10 stations), Akköy (10 stations). Seven samples from the upper levels (14.00-16.60 m) of the SK5 drill taken in Karşıyaka and one core sample in Babakale $(50 \mathrm{~cm})$ were also analyzed (Figure 1 and 2). Coordinates and some physical parameters of the stations are given in Table 1 and 2. 10 grams of wet sediment samples were weighed and treated with $10 \% \mathrm{H} 2 \mathrm{O} 2$ for 24 hours. The samples were washed with pressurized water on $0.063 \mathrm{~mm}$ sieve and dried at $50{ }^{\circ} \mathrm{C}$ in the oven. The dried samples were further sieved with $2.00,1.00,0.500,0.250$, $0.125 \mathrm{~mm}$ mesh sizes. The foraminifer individuals were separated under a binocular microscope.

\section{Systematics and Remarks}

Loeblich and Tapan, 1988 was used for systematics.

Superfamily CORNUSPIRACEA Schultze, 1854

Family Cornuspiridae Schultze, 1854

Subfamily Cornuspiroidinae, Saidova. 1981

Genus Cornuspiroides Cushman, 1928

Cornuspiroides striolatus (Brady), 1928

Cornuspiroides striolata was first described by Brady (1882) as Cornuspira striolata. Cushman (1928) has named the Atlantic specimens as Cornuspiroides striolata (Brady) (p. 3, pl. 1). Loeblich and Tappan (1994) and Debenay (2012) also used Cornuspiroides striolatus (Brady).

It is known to be distributed in the Pacific Ocean, in New Caledonia and Timor Sea (Loeblich and Tappan, 1994; Debenay, 2012). This species has been previously recorded in southeastern Sea of Marmara (Sakınç, 2008, Plate 2, Figure 10). Cimmerman and Langer (1991) have reported this species from Adriatic Sea, however the SEM photo they have given do not show the characteristics of the species, which suggests a misidentification (Plate 15, Figure 8). A total of 27 Cornuspiroides striolata (Brady) specimens, 6 of which are large and well preserved, are found in Ildir (stations 2, 3, 4, 5, 8, 9 and 10, Table 1, Figure 3). The highest abundance is observed in station 2 .

Superfamily CORNUSPIRACEA Schultze, 1854

Family Fischerinidae Millett, 1898

Subfamily Nodobaculariellinae Bogdanovich, 1981

Genus Nodobaculariella Cushman and Hanzawa, 1937

Nodobaculariella cristobalensis McCulloch (1977)

Nodobaculariella galapagosensis McCulloch (1977)

The genus Nodobaculariella was first described Nodobaculariella japonica Cushman and Hanzawa (1937). McCulloch (1977 and 1981) described Nodobaculariella cristobalensis and Nodobaculariella galapagosensis from Panama Canal zone and Galapagos Islands (p. 583, pl. 244, figs. 16-19 and p. 584, pl. 244, figs. 7-10).

Nodobaculariella cristobalensis McCulloch is abundantly observed in the sediment samples collected at $45.00 \mathrm{~m}$ of depth from two stations (Station 7 and 8) in Güllük Bay (Figure 2, 4 and 5). It is also found in the $0-25$ and $25-50 \mathrm{~cm}$ levels of the core sample collected from Babakale (Balıkesir, Gulf of Edremit) at $9.00 \mathrm{~m}$ of depth (Figure 1).

Both Nodobaculariella cristobalensis McCulloch and Nodobaculariella galapagosensis McCulloch were observed in the core sample SK-5 collected from Karşıyaka (Gulf of İzmir) during a marina construction (Figure 2 and 5). 6 samples between 14.00-16.50 $\mathrm{m}$ levels of the core were investigated and Nodobaculariella cristobalensis McCulloch were found to be abundant, but only two individuals of Nodobaculariella galapagosensis McCulloch were found.

Superfamily NODOSARIACEA Ehrenberg, 1838

Family Nodosariidae Ehrenberg, 1838

Subfamily Nodosariinae Ehrenberg, 1838

Genus Pseudonodosaria Boomgaart, 1949

Pseudonodosaria brevis (d'Orbigny, 1846) 
Table 1: Distribution of individuals among stations.

\begin{tabular}{|c|c|c|c|c|c|c|c|}
\hline Location & Station & $\begin{array}{l}\text { Lattitude }(\mathbf{N}) \\
\text { (degree, } \\
\text { minute) }\end{array}$ & $\begin{array}{c}\text { Longitude } \\
\text { (E) } \\
\text { (degree, } \\
\text { minute) } \\
\end{array}$ & $\begin{array}{c}\# \\
\text { Cornuspiroides } \\
\text { striolatus }\end{array}$ & $\begin{array}{c}\# \\
\text { Nodobaculariella } \\
\text { cristobalensis }\end{array}$ & $\begin{array}{c}\# \\
\text { Nodobaculariella } \\
\text { galapagosensis }\end{array}$ & $\begin{array}{c}\# \\
\begin{array}{c}\text { Pseudonodosaria } \\
\text { brevis }\end{array}\end{array}$ \\
\hline \multirow{10}{*}{ Ildir } & $\mathrm{I}-1$ & 3825.70 & 2626.51 & & & & \\
\hline & $\mathrm{I}-2$ & 3825.51 & 2626.09 & 17 & & & \\
\hline & $\mathrm{I}-3$ & 3825.51 & 2626.19 & 2 & & & \\
\hline & $\mathrm{I}-4$ & 3825.32 & 2626.09 & 2 & & & \\
\hline & $\mathrm{I}-5$ & 3825.32 & 2626.21 & 3 & & & 1 \\
\hline & I-6 & 3825.19 & 2625.95 & & & & \\
\hline & $\mathrm{I}-7$ & 3825.17 & 2625.80 & & & & \\
\hline & $\mathrm{I}-8$ & 3825.00 & 2625.54 & 1 & & & \\
\hline & I-9 & 3824.28 & 2624.51 & 1 & & & \\
\hline & I-10 & 3823.53 & 2623.47 & 1 & & & \\
\hline Akköy & A-8 & $37^{0} 27.99$ & $27^{0} 7.14$ & & & & 1 \\
\hline \multirow{2}{*}{ Güllük } & G-7 & 3710.40 & 2727.44 & & 4 & & \\
\hline & G-8 & 3710.60 & 2727.21 & & 5 & & \\
\hline Karşıyaka & SK-5 & 3827.10 & 2707.10 & & 7 & 2 & \\
\hline Babakale & UD & 3928.47 & 2603.99 & & 6 & & \\
\hline
\end{tabular}

Table 2. Maximum and minimum values of some physical parameters observed in Ildır Bay, Güllük Bay and Akköy in April 2014.

\begin{tabular}{|l|c|c|c|}
\hline & Ildır Bay & Güllük Bay & Akköy \\
\hline Temperature ('C) & $17.50-17.98$ & $17.80-18.25$ & $17.29-17.94$ \\
\hline Salinity (ppt) & $38.97-39.00$ & $39.09-39.18$ & $39.18-39.19$ \\
\hline pH & $8.03-8.22$ & $8.09-8.19$ & $8.13-8.20$ \\
\hline Diss. Oygen (mg/l) & $6.87-7.42$ & $6.80-7.49$ & $6.85-7.28$ \\
\hline Depth (m) & $66-67$ & $44-53$ & $67-68$ \\
\hline
\end{tabular}




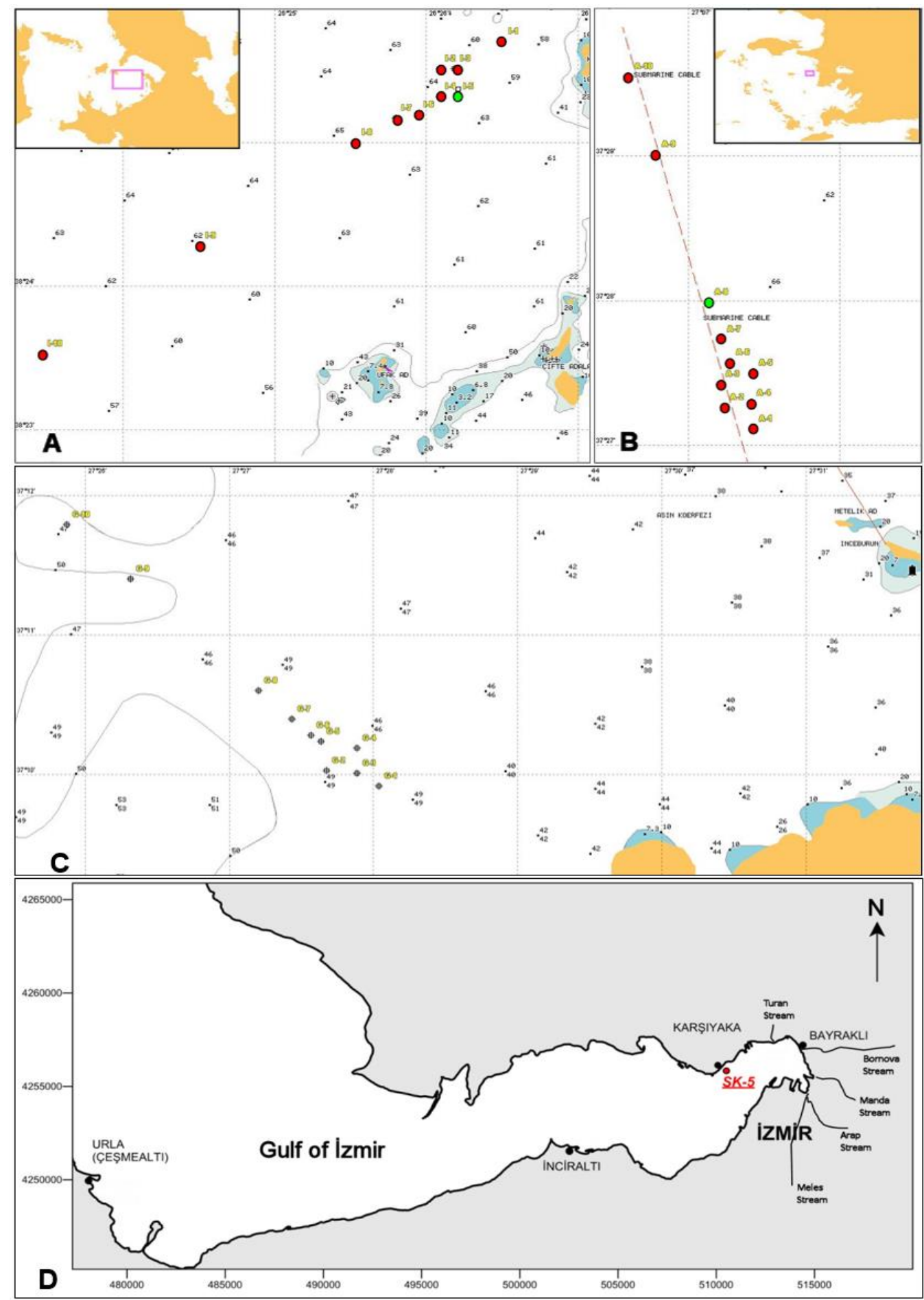

Fig. 2. Sampling stations and drill locations: A) Ildır; B) Akköy, C) Güllük; D) Gulf of Izmir. 
Pseudonodosaria brevis was first described as Nodosaria brevis by d'Orbigny (1846). Reuss (1850) described it as Glandulina discreta and it was changed to Pseudonodosaria discreta (Reuss) by Boomgaart (1951). Pseudonodosaria discreta (Reuss) was used in several later studies (Loeblich and Tappan 1955; Loeblich and Tappan 1994; Yassini and Jones 1995).
New Caledonia (Debenay 2013), Sahul Shelf and Timor Sea (Loeblich and Tapman, 1994). Two individuals of Pseudonodosaria brevis (d'Orbigny, 1846) were found in the sediment samples from Ildır Bay (İzmir) and Akköy (Aydin) which have been collected from depths of 66-68 $\mathrm{m}$ (Figure 2 and 6) This is the first record of this species from the Mediterranean.

Pseudonodosaria brevis has been known to inhabit New Zealand waters (Hayward 2015),

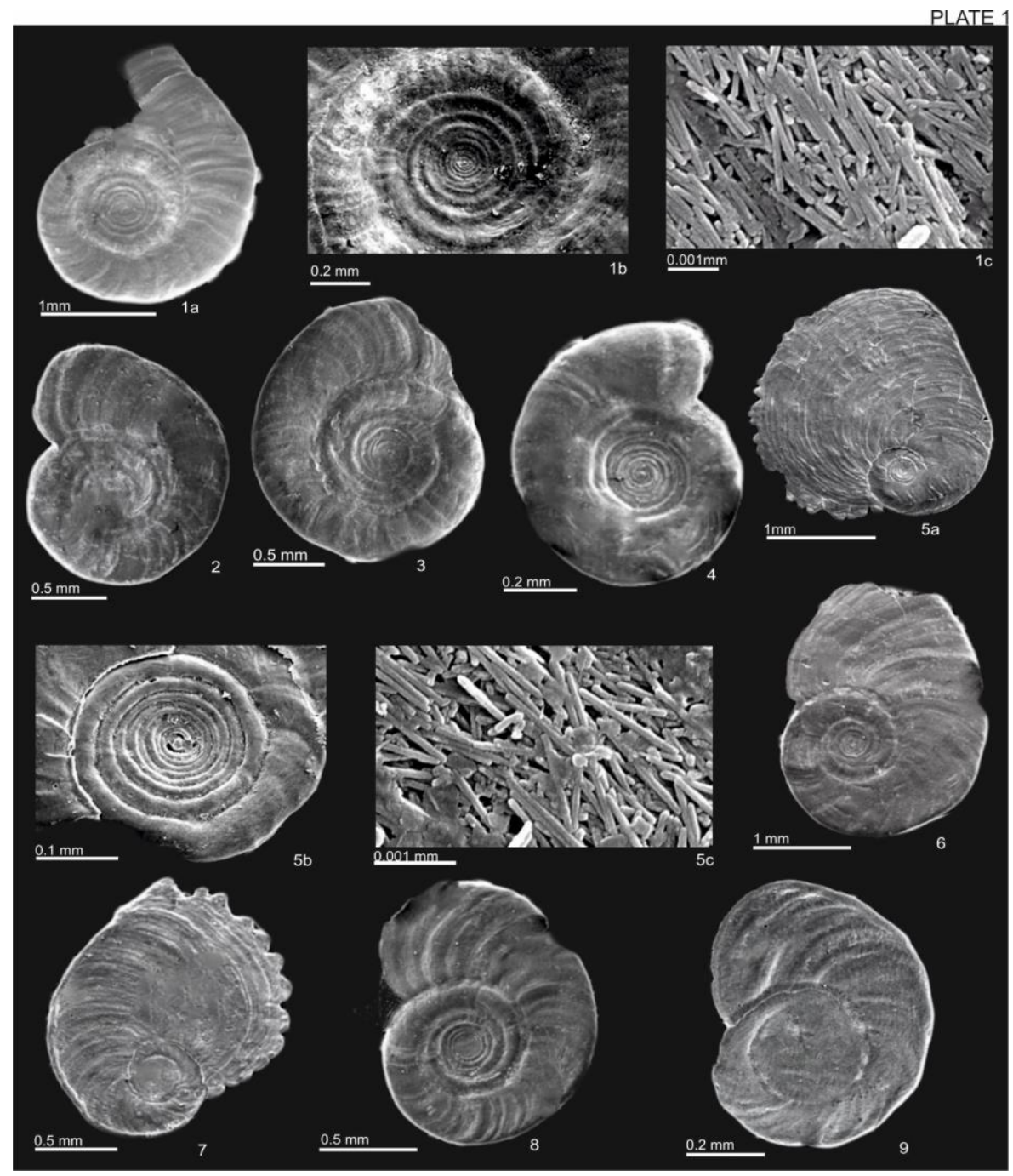

Fig. 3. Cornuspiroides striolatus (Brady) specimens. 1) a, side view and b, central part of the test, c, detailed view of the test, Ildır Bay, sample 2, 66.00 m. 2) Side view, Ildır Bay, sample 5, 67.00 m. 3) Side view, Ildır Bay, sample 5, 67.00 m. 4) Side view, Ildır Bay, sample 10,66.00 m. 5). a, side view, b, central part of the test, c, detailed view of the test, Ildır Bay, sample 2, 66.00 m. 6) Side view, Ildır Bay, sample 2, 66.00 m. 7) Side view, Ildır Bay, sample 2, 66.00 m. 8) Side view, Ildır Bay, sample 2, 66.00 m. 9) Side view, Ildır Bay, sample 2, $66.00 \mathrm{~m}$. 


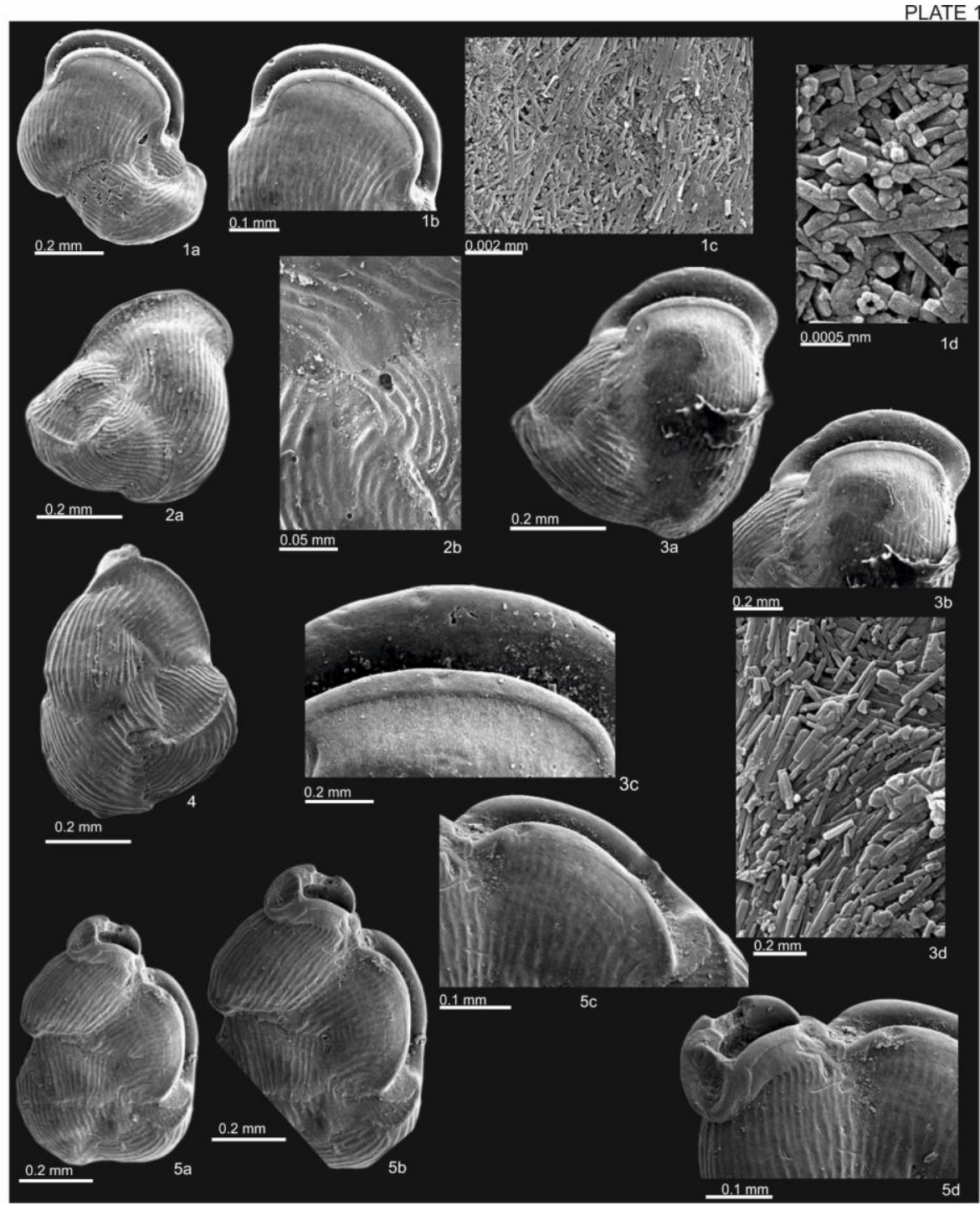

Fig. 4. Nodobaculariella cristobalensis McCulloch specimens. 1) a, side view; b, aperture; c and d. detailed view of the test, Güllük Bay, sample $8,45.00 \mathrm{~m}$. 2) a, side view, b, details of the side view, Güllük Bay, sample 8, $45.00 \mathrm{~m}$. 3) a, side view, b, aperture, c, detailed view of aperture, d, detailed view of the test, Güllük Bay, sample $8,45.00 \mathrm{~m}$. 4) Side view, Güllük Bay, sample $8,45.00$ m. 5) a, side view, b, two aperture, c and d, detailed view of apertures, Güllük Bay, sample 8, $45.00 \mathrm{~m}$.

\section{Conclusion}

Foraminiferal assemblages of the Aegean and Levantine coasts of Turkey have been extensively studied (Meriç et al. 2004; Meriç et al. 2008a, b; Meriç et al. 2010; Meriç et al. 2011; Meriç et al. 2012a, b). Recent findings of these species indicate new introductions to the region. Our findings suggest that these alien foraminifers might have been introduced to the Aegean Sea via ballast waters. It was reported that nearly $70 \%$ of the marine alien species introduced by ships in the Aegean Sea were recorded in Gulf of Izmir (Cinar et al. 2005). Some of these records are quite historical, being the first records of alien species from the Mediterranean (Quatrefages, 1865). The nearby İzmir harbor has a heavy maritime traffic; thus it may be the main cause of these introductions. The finding of Nodobaculariella galapagosensis McCulloch and Nodobaculariella cristobalensis 
McCulloch in the 14.00-16.50 m levels of the core sample from Karşiyaka suggests that these species might have been introduced to the antique harbor not in the very near past, and buried because of the high sedimentation rate due to five streams in the gulf (Figure 2D).

There are few other examples of alien foraminifer introductions observed in the
Eastern Aegean coasts which might have been used the same way of introduction, such as, Iridia diaphana Heron-Allen and Earland, Euthymonacha polita (Chapman), Coscinospira acicularis (Batsch) and Polymorphina fistulosa (Cushman) (Meriç et al., 2008b; 2010; 2011 and 2012a).

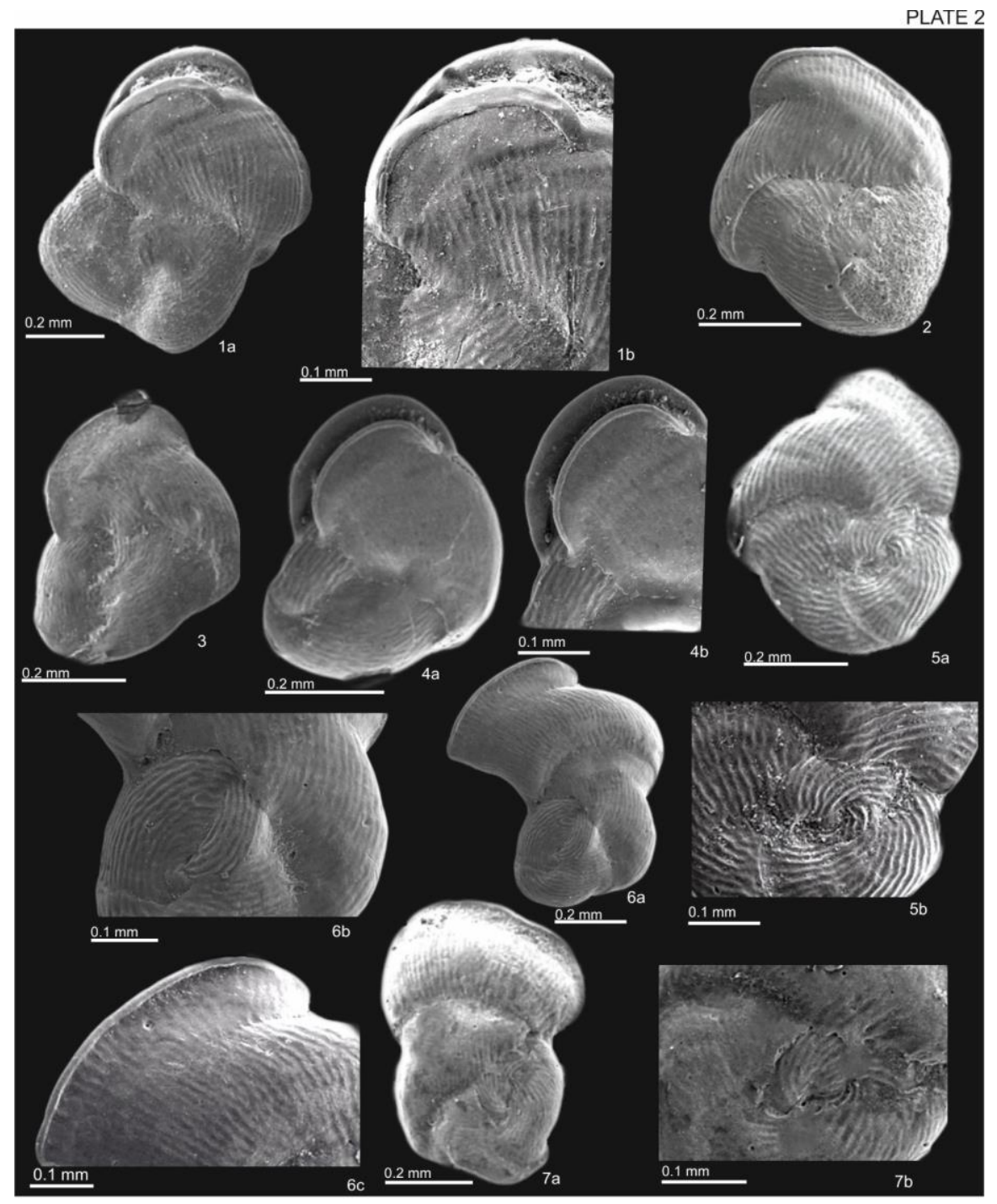

Fig 5. Nodobaculariella cristobalensis McCulloch (1-5) and Nodobaculariella galapagosensis McCulloch (6-7) specimens. 1) a, Side view and b, aperture, Güllük Bay, sample 7, 45.00 m. 2) Side view, Güllük Bay sample 7, 45.00 m. 3) Side view, Güllük Bay sample 7, 45.00 m. 4) a, Side view and b, aperture, Gulf of İzmir, Karşıyaka drill-hole, SK-5, 14.00-14.05 m. 5) a, Side view and b, details of the side view, Gulf of Izmir, Karşıyaka drill-hole SK5, 14.20-14.25 m. 6) a, side view and b, details of the side view, c, aperture, Gulf of Izmir, Karşıyaka drill-hole SK-5, 16.00-16.05 m. 7) a, side view and b, details of the side view, Gulf of Izmir, Karşıyaka drill-hole SK-5, 16.40-16.45 m. 
Cornuspiroides striolatus (Brady) and Nodobaculariella cristobalensis McCulloch are found to be locally restricted but abundant (Table 1). Only two individuals of Pseudonodosaria brevis (d'Orbigny) were yet found, however $100 \mathrm{Km}$ distance between the two stations indicates the presence of a rare but established population. It has been shown that thermophilic alien foraminifer species form dense populations around submarine springs located on the eastern Aegean (Meriç et al. 2010; Meriç et al. 2011). There are numerous hot waters springs located on the active fault lines on the Eastern Aegean coastline. Presence of Peneroplis pertusus (Forskal) and $P$. planatus
(Fichtel and Moll) in Babakale and Asos (Gulf of Edremit) indicates suitable thermal conditions for these thermophilic species to establish stable populations. Meriç et al. (2003) reports Peneroplis spp. from two different locations in the Gulf of Edremit, and the presence of warm springs along the coastline supports the idea of submarine springs. Thus, the thermophilic species reported in this study might have found suitable conditions to form established populations around the warm submarine springs located around these fault lines and they might have found enough time to adapt and spread along the Eastern Aegean by the local currents.

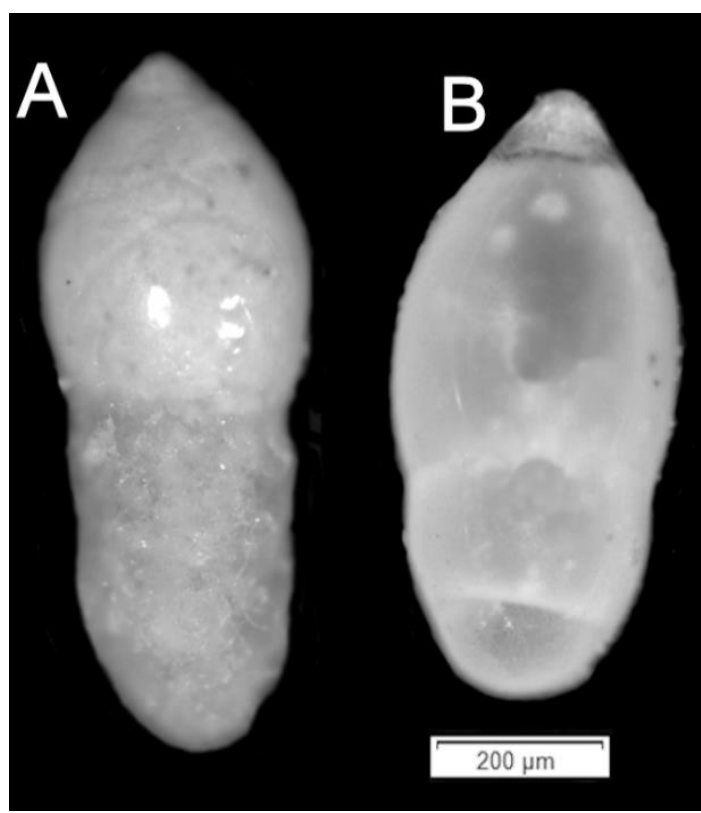

Fig 6. Stereo microscope photos of the Pseudonodosaria brevis (d'Orbigny) specimens collected from A) Ildır Bay; B) Akköy.

\section{Acknowledgements}

Authors would like to thank Prof. Dr. Ferah KOÇAK (Dokuz Eylül University) for her contribution in sample collection. The authors are also grateful to Assoc.Prof. Salim ÖNCEL (Gebze Technical University) and Physicist Ahmet NAZIM (Gebze Technical University) for SEM photography.

\section{References}

Boomgaart L (1951) Smaller foraminifera from Bodjonegoro (Java). Sappemeer, Smit and Dontje, 1949, 175 p.

Brady, H. B., 1882, in Tizard, Staff-C ommander and Murray, J., 1882, Exploration of the Faröe Channel during the summer of 1880, in her Majesty's hired ship "Knight-Errand". Proceedings of the Royal Society of Edirburgh 11, 638-720. 
Cimmerman F. and Langer M.R. (1991) Mediterranean foraminifera.Ljubljana, Slovenia: Slovenska Akademija Znanosti in Umetnosti,Akademia Scientiarum et Artium Slovenica, 118 pp., 93 pls.

Çınar M. E., Bilecenoğlu M., Öztürk B, Katagan T, and Aysel V., 2005, Alien species on the coasts of Turkey. Mediterranean Marine Science, 6(2): 119-146

Cushman, J. A., 1928, Additional genera of the foraminifera, Contributions from Cushman Laboratory for Foraminiferal Research, 4, 18.

Cushman, J. A., Hanzawa, S., 1937, Notes on some of the species referred to Vertebralina and Articulina, and a new genus Nodobaculariella. Contribution from the Cushman Laboratory for Foraminiferal Research, 11, 41-46.

Debenay J-P 2013, A guide to 1,000 Foraminifera from the Southwestern Pacific New Caledonia. IRD Editions. Publication Scientifique du Museum. CP41, 383 pp. available online at http://www.ird.fr/editions/catalogue/ouvrage .php?livre $=677$

Hayward B (2015) Pseudonodosaria brevis. In: Hayward, B.W., Cedhagen, T., Kaminski, M., Gross, O. (2015) World Foraminifera Database. Accessed through: World Register of Marine Species at http://marinespecies.org/aphia.php? $\mathrm{p}=$ taxdet ails\&id=466129 on 2015-06-19

Loeblich Jr AR, Tappan H (1955) A revision of some Glanduline Nodosariidae (Foraminifera), Smithsonian Miscellaneous Collections 126 (3), 1-9.

Loeblich, Jr. A. R. and Tappan, H., 1988, Foraminiferal genera and their classification. Van Nostrand Reinhold Company, 970 p., 842 plts., New York.

Loeblich, Jr. A. R. and Tappan, H., 1994, Foraminifera of the Sahul Shelf and Timor Sea. Cushman Foundation for Foraminiferal Research, Special Publication, No: 31, 663 p., 630 plts.

McCulloch, I., 1977, Qualitative observations on recent foraminiferal tests with emphasis on the eastern Pacific. Part I, II, III, PhD. Thesis. University of Southern California, Los Angeles, California 90007.
McCulloch, I., 1981, Qualitative observations on recent foraminiferal tests with emphasis on the Allan Hancock Atlantic expedition collections. Part IV, PhD. Thesis. University of Southern California, Los Angeles, California 90007.

Meriç E, Avşar N, Bergin F (2004) Benthic foraminifera of Eastern Aegean Sea (Turkey) Systematics and Autoecology. Turkish Marine Research Foundation and Chamber Of Geological Engineers of Turkey, Publication No: 18: 306 pages and 33 plates, İstanbul.

Meriç E, Avşar N, Yokeş B (2008a) Some alien foraminifers along the Aegean and southwestern coasts of Turkey. Micropaleontology, in: Recent benthic foraminifera along the southwest coasts of Antalya (SW Turkey) and the impact of alien species on authocthonous fauna (eds. E. Meriç and M. B. Yokeş), 54 (3-4), 307-349.

Meriç E, Avşar N, Yokeş B, Dinçer F (2008b) Alibey ve Maden adaları (Ayvalık-Balıkesir) yakın çevresi bentik foraminiferlerinin taksonomik dağılımı. MTA Dergisi, 137, 4965, Ankara.

Meriç E, Yokeş B, Avşar N (2011) A new guest in Ilıca Bay (Çeşme-İzmir-Turkey): Coscinospira acicularis. Journal of Marine Biological Association of the United Kingdom, 4, e94, 1-5.

Meriç E, Yokeş B, Avşar N, Kırcı-Elmas E, Dinçer F (2012a) A new record in eastern Aegean Sea (Turkey): Polymorphina fistulosa. Marine Biodiversity Records,1-3, Marine Biological Association of the United Kingdom, doi:10.1017/s1755267212000863， 5, e103; published on line.

Meriç E, Yokeş MB, Avşar N, Bircan C (2010) An oasis for alien benthic foraminifera in the Aegean Sea. Aquatic Invasions, 5 (2), 191195.

Meriç E, Yokeş MB, Avşar N, Kırcı-Elmas E, Dinçer F, Karhan SÜ, Kalkan E, Demir V (2012b) First Report of Pararotalia calcariformata McCulloch From The Hatay Coastline (Turkey - NE Mediterranean). Marine Biodiversity Records, 6(e31):1-4, DOI:10.1017/S1755267212001108. 
Meriç, E., Avşar, N., Bergin, F., Barut, İ. F., 2003, Edremit Körfezi (Kuzey Ege Denizi, Türkiye) güncel çökellerindeki bentik foraminifer topluluğu ile ekolojik koşulların incelenmesi. Yerbilimleri (Geosound), 43, 169-182, Adana.

Okuş, E., Sur, HI, Yüksek, A., Yılmaz, IN, AslanYımaz, A., Karhan, SÜ, Öz, Mİ, Demirel, N, Taş, S, Altıok, H. and Gazioğlu, C. (2004). Datça-Bozburun özel çevre koruma bölgesinin denizsel ve kıyısal alanlarının biyolojik çeşitliliğinin tespiti projesi, Ankara: TC Çevre ve Orman Bakanlığı ÖÇKK Başkanlığı.

Okuş, E., Sur, HI, Yüksek, A., Yılmaz, IN, AslanYımaz, A., Karhan, SÜ, Öz, Mİ, Demirel, N, Taş, S, Altıok, H. and Gazioğlu, C. (2006). Gökova özel çevre koruma bölgesinin denizsel ve kıyısal alanlarının biyolojik çeşitliliğinin tespiti projesi, Ankara: TC Çevre ve Orman Bakanlığı ÖÇKK Başkanlığı.

Quatrefages M. A., 1865. Histoire naturelle des Annélides marins et d'eau douce, Annélides et Gephyriens, 2. Sedentaira (Paris), 562 pp.

Reuss AE (1850) Neue foraminiferen aus den schichten des österreischen Tertiarbeckens. Denkschriften der Kaiserlichen Akademie der Wissenschaften, MathematischNaturwissenschaftliche Classe 1, 365-390.

Sakınç M (2008) Marmara Denizi Bentik Foraminiferleri: Sistematik ve Otoekoloji. Istanbul Üniversitesi Rektörlüğü, publication no: $1638,134 \mathrm{pp}$.

Yassini I, Jones BG (1995) Foraminiferida and Ostracoda from estuarine and shelf environments on the southeastern coast of Australia. The University of Wollongong Press, 269 p.
Zenetos A, Gofas S, Morri C, Rosso A, Violanti D, García Raso JE, Çinar ME, Almogi-Labin A, Ates AS, Azzurro E, Ballesteros E, Bianchi CN, Bilecenoglu M, Gambi MC, Giangrande A, Gravili C, Hyams-Kaphzan O, Karachle PK, Katsanevakis S, Lipej L, Mastrototaro F, Mineur F, PancucciPapadopoulou MA, Ramos Esplá A, Salas C, San Martín G, Sfriso A, Streftaris N, Verlaque M (2012) Alien species in the Mediterranean Sea by 2012. A contribution to the application of European Union's Marine Strategy Framework Directive (MSFD). Part 2. Introduction trends and pathways. Mediterranean Marine Science, 13: 328-352.

Zenetos A, Meriç E, Verlaque M, Galli P, Boudouresque C-F, Giangrande A, Çınar ME, Bilecenoğlu M (2008) Additions to the annotated list of marine alien biota in the Mediterranean. with special emphasis on Foraminifera and Parasites. Mediterranean Marine Science, 9 (1), 119-165. 